\title{
EDUCATION FOR COMMUNITY IN EFFORTS TO PREVENT DRUG USED IN SEI PANGERAN KECAMATAN ILIR TIMUR I PALEMBANG
}

\author{
Ridwan, Sherli Shobur, Sulaiman \\ Jurusan Keperawatan Poltekkes Palembang, \\ iwaninderalaya30@gmail.com.
}

\begin{abstract}
Background, Data Badan Narkotika Nasional in 2019, there was an increase in drug trafficking from the previous year of 0.03 percent. It is estimated that the number of users of 3,600,000 people, the most between the ages of 15 to 65 years. In South Sumatra Province, the data on drug abuse that the South Sumatra BNNP rehabilitated in 2019 were 965 people in 2020, as many as 976 people. Drug dealers in Palembang, South Sumatera, have changed their recruitment of dealers, targeting homemakers and students on college campuses. Purpose, this educational activity on the prevention of drug use aims to increase public knowledge of drug abuse methods, using counseling methods and distributing leaflets before counseling is carried out the first measurement. They were then monitoring the next two weeks on the target group of 66 participants. As a result, there was an increase in the target group's knowledge before and after counseling. In conclusion, the method of extension is one of the effective media to educate the public on the prevention of drug use.
\end{abstract}

Keywords: Prevention, used, drugs

\begin{abstract}
Abstrak
Data dari Badan Narkotika Nasional pada tahun 2019 terjadi peningkatan peredaran Narkoba dari tahun sebelumnya sebesar 0.03 persen. Diperkirakan angka pengguna 3.600 .000 orang dimana usia yang paling banyak dikisaran 15 hingga 65 tahun.di Propinsi Sumatera Selatan data penyalahgunaan Narkoba yang di rehabilitasi BNNP Sumsel pada tahun 2019 sebanyak 965 orang ditahun 2020 sebanyak 976 orang. Pengedar narkoba di Palembang, Sumatera Selatan sudah merubah perekrutan pengedar sudah menyasar para ibu rumah tangga juga mahasiswa di kampus-kampus Perguruan Tinggi. Tujuan, Kegiatan edukasi tentang Pencegahan penggunaan Napza ini bertujuan meningkatkan pengetahuan masyarakat terhadap penyalahgunaan Napza Metode, menggunakan metode penyuluhan serta membagikan leaflet, sebelkumpenyuluhan dilakukan pengukuran pertama,,, kemudian dilakukan monitoring pada dua minggu selanjnutnya pada kelompok sasaran sejumlah 66 peserta. Hasil, terjadi peningkatan pengetahuan kelompok sasaran dari sebelum dan sesudah dilakukan penyuluhan.Kesimpulan, metode penyuluhan merupakan salah satu media efektif untuk memberikan edukasi kepada masyarakat terhadap pencegahan penggunaan Napza.
\end{abstract}

Kata kunci: Pencegahan, penggunaan, Napza 


\section{PENDAHULUAN}

Zat adiktif bila dimasukkan kedalam tubuh manusia baik secara oral, diminum, dihirup maupun disuntikkan dapat menyebabkan seseorang menjadi kecanduan, hal yang demikian pada Narkoba yang dapat mengubah pikiran, suasana hati atau perasaan, dan tinkahlaku seseorang. Dalam dunia medis atau kedokteran narkoba senyawa psikotropika biasa dipakai untuk membius pasien saat hendak dioperasi, untuk menghilangkan rasa sakit pada luka bakar atau obatobatan untuk penyakit tertentu seperti kanker. Namun dewasa ini zat psikotropika tersebut disalahgunakan akibat pemakaian di luar dosis dan anjuran dokteruntuk memberikan efek samping yang didapat dari penggunaaan zat psikotropika tersebut. Narkoba sudah menjadi ancaman bagi masyarakat, berbagai instansi mulai dari Kepolisian, Tokoh Masyarakat, tokoh agama, maupun BNN telah mengkampanyekan anti narkoba serta penanggulangan terhadap orang-orang yang sudah ketergantungan narkoba. Ancaman bahaa penyalahgunaan Narkotika di Indonesia kian meningkat dari tahun ke tahun terutama menyasar generasi muda bahkan anak anak sekolah dari Sekolah dasar sampai Perguruan Tinggi. Kejadian penyalahgunaan Narkotika di kota besar relatif tinggi dibandingkan di Kabupaten, dikarenakan siswa maupun mahasiswa merupakan target dan sasaran dalam penyalahgunaan Narkotika. Data Badan Narkotika Nasional pada tahun 2019 terjadi peningkatan peredaran Narkoba dari tahun sebelumnya sebesar 0.03 persen. Diperkirakan angka pengguna 3.600.000 orang dimana usia yang paling banyak dikisaran 15 hingga 65 tahun.di Propinsi Sumatera Selatan data penyalahgunaan Narkoba yang di rehabilitasi BNNP Sumsel pada tahun 2019 sebanyak 965 orang ditahun 2020 sebanyak 976 orang. . Pengedar narkoba di Palembang, Sumatera Selatan sudah merubah perekrutan pengedar sudah menyasar para ibu rumah tangga juga mahasiswa di kampus-kampus Perguruan Tinggi. Seperti penangkapan sindikat pengedar narkoba di Palembang oleh Satres Narkoba Polrestabes Palembang. Dari tiga tersangka pengedar narkoba, salah satunya tercatat sebagai mahasiswi di Perguruan Tinggi Swasta di Palembang.(31/8/2020). Ancaman hukum bagi penyalagunaan Narkotika menurut Undang undang RI no 35 tahun 2009 tentang Narkotika pada Pasal 111, Ayat 1; Setiap orang yang tanpa hak atau melawan hukum menanam, memelihara, memiliki, menyimpan, menguasai atau menyediakan Narkotika golongan 1 dipidana paling sedikit 4 tahun paling lama 12 tahun atau denda paling sedikit 800 juta paling banyak Rp 8 Miliar, faktanya masih banyak orang tidak takut akan ancaman tersebut. Oleh sebab itu pendidikan kesehatan tentang bahaya penggunaan Narkotika perlu digalakkan sejak dini, mulai dari lingkungan keluarga, masyarakat, Sekolah, tempat kerja.Salah satu pendekatan yang paling mudah dilakukan adalah edukasi atau penyuluhan yang dilakukan secara terus 
Ridwan, dkk. Education For Community In Efforts To Prevent Drug Used In Sei ...

menerus terutama kepada anggota keluarga yang memiliki anak anak dalam usia remaja yang masih labil dalam pola fikir serta peegaulan sehari hari.

\section{METODE}

Permasalahan pada kelompok sasaran (mitra) yaitu masih rendahnya pemahaman masyarakat tentang bahaya penggunaan Napza, selain itu masih kurangnya informasi serta penyuluhan kepada masyarakat, sehingga memungkinkan anggota masyarakat menggunakan Napza yang paling umum adalah penggunaan zat zat adiktif dikalangan remaja seperti halnya Merokok dan menghirup zat zat inhaler yang membahayakan kesehatan misalnya Aica aibon.

Kegiatan pengabdian kepada masyarakat dilaksanakan di RT 37 RW 07 Kelurahan Sei Pangeran Kecamatan Ilir Timur I Palembang, yang diselenggarakan sebanyak 2 (dua) kali penyuluhan serta diakhiri dengan evaluasi kegiatan yang diselenggarakan pertama tanggal 30 September 2020 dan kedua 13 Oktober 2020.

Kegiatan PKM ini didilaksanakan oleh 3 dosen dan dibantu 5 mahasiswa DIII Keperawatan. Pada kegiatan ini mahasiswa bertugas membantu menyiapkan alat dan bahan yang digunakan untuk, pengisian daftar hadir, serta membagikan questioner sebelum serta sesudah PKM kepada kelompok sasaran.

Tahapan pelaksanaan kegiatan difokuskan pada kegiatan.
1. Pengukuran pengetahuan sebelum dilakukan penyuluhan pada tahab pertama.

2. Penyuluhan pemberian materi dan pembahian leaflet.

3. Pengukuran pengetahuan sesudah dilakukan kegiatan pada tahab kedua

\section{HASIL DAN PEMBAHASAN}

Program ini merupakan Pengabdian Kepada Masyarakat yang lebih difokuskan pada kegiatan Penyuluhan, serta diskusi tentang Napza adapun hasil yang diperoleh adalah

Rata rata pengetahuan sebelum dilaksanakan penyuluhan sebesar 4.85 dengan standar deviasi 0.769. Pada pengukuran kedua sesudah dilaksanakan penyuluhan didapat rata rata pengetahuan responden sebesar 6.41 dengan standar deviai 0.554 .

Terlihat nilai mean perbedaan antara sebelum dan sesudah pelaksanaan pengabmas, Sehingga didapat peningkatan pengetahuan kelompok sasaran didalam edukasi tentang Napza didalam pencegahan penggunaan Napza di Kel Sei Pangeran Kecamatan Ilir Timur I Palembang

Kegiatan ini dilaksanakan dengan pemberian materi kepada kelompok sasaran seputar Napza, masyarakat sangat antusias mengikuti acara PKM ini.

Tabel 1. Hasil Pendataan kelompok Sasaran

\begin{tabular}{ccc} 
Variabel & Jumlah & $\mathbf{\%}$ \\
\hline Jenis kelamin & & \\
Laki laki & 22 & 33.3 \\
Perempuan & 44 & 66.7 \\
Rata rata Usia & & \\
Usia minimum & 40.8 & \\
\hline
\end{tabular}




\begin{tabular}{lcc}
\hline \multicolumn{1}{c}{ Usia Maksimum } & 29 th & \\
Pekerjaan & & \\
$\quad$ Bekerja & 57 & \\
Tidak bekerja & & \\
Pendidikan & 34 & 51,5 \\
SD & 32 & 48,5 \\
SMP & & \\
SMA & 2 & 3 \\
PT & 19 & 28.8 \\
& 43 & 65.2 \\
& 2 & 3 \\
\hline
\end{tabular}

Tabel 2. Hasil Pengukuran sebelum dan sesudah Penyuluhan pada kelompok sasaran

\begin{tabular}{cccccc}
\multicolumn{9}{c}{ kelompok sasaran } \\
\hline Variabel & $\begin{array}{c}\text { Me } \\
\text { an }\end{array}$ & SD & SE & $\begin{array}{c}\text { p } \\
\text { Val } \\
\text { ue }\end{array}$ & $\mathrm{n}$ \\
\hline $\begin{array}{c}\text { Pengetahuan } \\
\text { Sebelum }\end{array}$ & 4.85 & 0.769 & 0.095 & 0.00 & 66 \\
Sesudah & 6.41 & 0.554 & 0.068 & & \\
\hline
\end{tabular}

Hambatan yang ditemuklan selama melaksanakan kegiatan Penyuluhan ini adalah lokasi penyuluhan yang agak sempit menggunakan bahu jalan, karena tidak ada ruangan yang cukup besar untuk menampung semua kelompok sasaran, Proses penyuluhan agak terhenti beberapa saat bila ada kendaraan yang akan lewat, sihingga sedikit mengganggu konsentrasi perhatian kelompok sasaran.
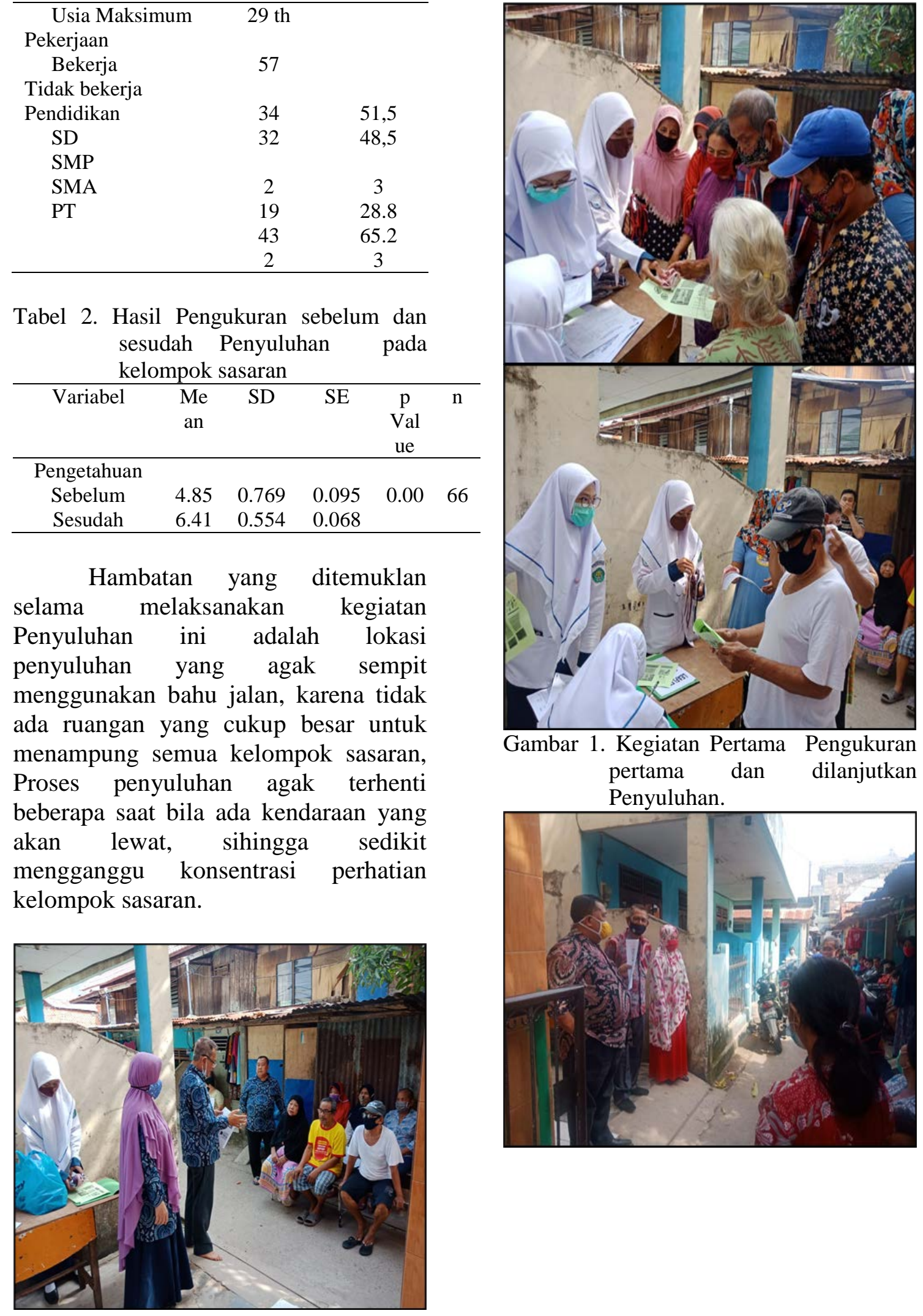
Ridwan, dkk. Education For Community In Efforts To Prevent Drug Used In Sei ...

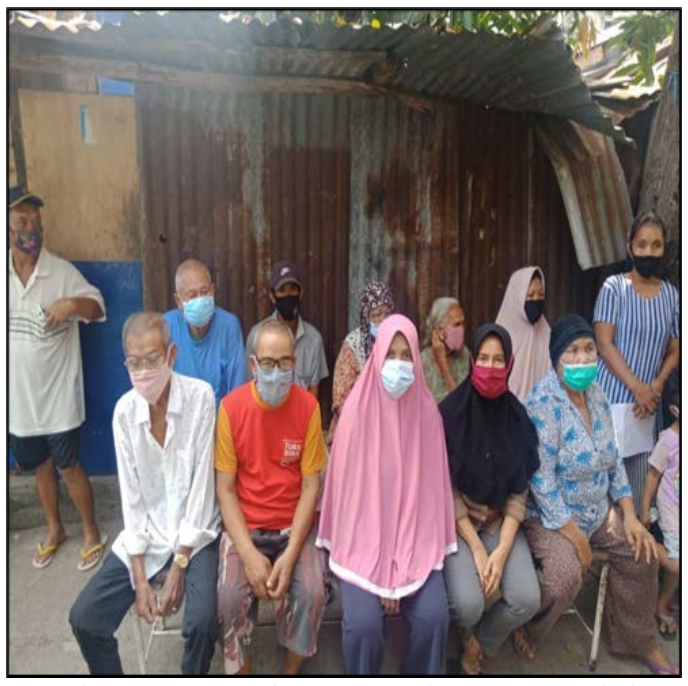

Gambar 2. Kegiatan Kedua, Penyeluhan dan diakhiri dengan pengukuran kedua

$\begin{array}{lrrr} & \text { Walaupun } & \text { demikian kelompok } \\ \text { sasaran sangat antusias dalam } \\ \text { mengikuri } & \text { Penyuluhan didalam }\end{array}$
Pengabdian Kepada Masyarakat di RT 37 RW 07 Kel Sei Pangeran Kecamatan Ilir Timur I Palembang.

Hasil pengukuran pertama dan kedua nampak peningkatan pengetahuan kelompok sasaran didalam upaya pencegehan Penggunaan Napza sehingga perlu dilaksanakan penyuluhan yang berkesinambungan pada kelompok sasaran tersebut.

\section{SIMPULAN}

Adapun kesimpulan dari kegiatan Pengabdian Kepada Masyarakat ini sebagai berikut

1. Kegiatan pertama PKM adalah pengukuran dan penyuluhan kepada kelompok sasaran didalam upaya pencegahan penggunaan Napza di lingkungan keluarga.

2. Kegiatan Kedua dilakukan Penyuluhan yang diikuti kelompok sasaran, Toma dan Toga.
3. Kegiatan terakhir dilakukan pengukuran pengetahuan kembali dari hasil penyuluhan sebelumnya.

4. Hasil yang diperoleh adalah peningatan pengetahuan kelompok sasaran terhadap pencegahan penggunaan Napza di masyarakat.

\section{UCAPAN TERIMA KASIH}

Penulis mengucapkan terima kasih kepada Poltekkes Kemenkes Palembang yang telah memberikan dukungan Dana terhadap Pengabmas ini, tak lupa kami ucapkan terima kasih kepada Bapak RT 37 RW 07, Bapak Lurah Kel Sei Pangeran dan bapak Camat Ilur Timur I Palembang yang telah memfasilitasi kegiatan ini sehingga dapat berjalan dengan baik dan lancar.

\section{DAFTAR PUSTAKA}

Badan Narkotika Nasional, Deputi Pencegahan Direktorat Diseminasi Informasi, 2012. Mahasiswa dan Bahaya Narkotika

DaradjatZ, 2005. Pendidikan Islam dalam keluarga dan Sekolah, Jakarta, Ruhama

Kwan,SYL, Petersen PE, Pine CM, Health Promoting School; an opportunity for oral health promotion, Buletin of the world healt organization, 2005.

Peraturan Menteri Pendidikan dan kKebuadayaan RI No, 146 tahun 2014 tentang Kurikulum Pendidikan. 
Shewiham A. 2005 Oral health, general health and quality of Life, Buletin of the world Health Organization .

Tafsir A, 2008 Ilmu pendidikan dalam persfektif islam, Bandung Rosdakarya

Modul Bahan ajar Napza. Jurusan Keperawatan poltekkes Palembang (no Publish).

https://bnn.go.id/penggunaan-narkotikakalangan-remaja-meningkat/. https://www.iglobalnews.co.id/2019/09/ provinsi-sumsel :https://news.okezone.com/read/2018/1 1/27/610/1983707/puluhanribu-pemuda-di palembangkonsumsi-narkoba 